\title{
An old 'new' friend: postmeasles blindness in the 21st century
}

\author{
Ines Leal, David Cordeiro Sousa, Filomena Pinto, Walter Rodrigues
}

Department of Ophthalmology, Hospital de Santa MariaLisbon Academic Medical Center, Lisbon, Portugal

Correspondence to Dr Ines Leal, inescardosoleal@gmail.com

Accepted 26 October 2015
CrossMark

To cite: Leal I, Sousa DC,
Pinto F, et al. BMJ Case Rep
Published online: [please
include Day Month Year]
doi:10.1136/bcr-2015-
211766

To cite: Leal I, Sousa DC, Pinto F, et al. BMJ Case Rep include Day Month Year 211766

\section{DESCRIPTION}

Measles is a highly contagious illness caused by a morbillivirus. As a consequence of high vaccination coverage in developed countries, many countries have declared this disease eliminated. ${ }^{1}$ Measles can lead to serious complications such as pneumonia, encephalitis and death. The virus is sight threatening, ultimately causing corneal dryness and scarring. Measles keratitis is the most concerning ophthalmological complication, as it can lead to adherent leucoma, corneal ulceration, perforation and, eventually, phthisis bulbi. ${ }^{1}{ }^{2}$ We report a case of a 32-year-old African patient who presented due to decreased visual acuity for 25 years. His medical history was blameless, except for the occurrence of progressive bilateral vision loss following a measles infection at the age of 7 years. He presented written clinical records describing a past episode of keratoconjunctivitis following measles. $\mathrm{He}$ was unvaccinated. On observation, best-corrected visual acuity was hand movement perception OU (oculus uterque). Biomicroscopy revealed bilateral old corneal scarring with a dense adherent corneal leucoma and 6 o'clock pupil distortion (figures 1 and 2). There was no corneal perforation. B-scan ultrasonography was unremarkable for changes in the posterior segment of both eyes. Work up revealed no abnormalities except for positive antimeasles IgG. Since the condition is bilateral, the patient is awaiting corneal transplant. Although highly suggestive of postmeasles blindness, other causes of corneal opacification and scarring such as trauma, trachoma, the use of traditional eye medicines and leprosy should be taken into account.

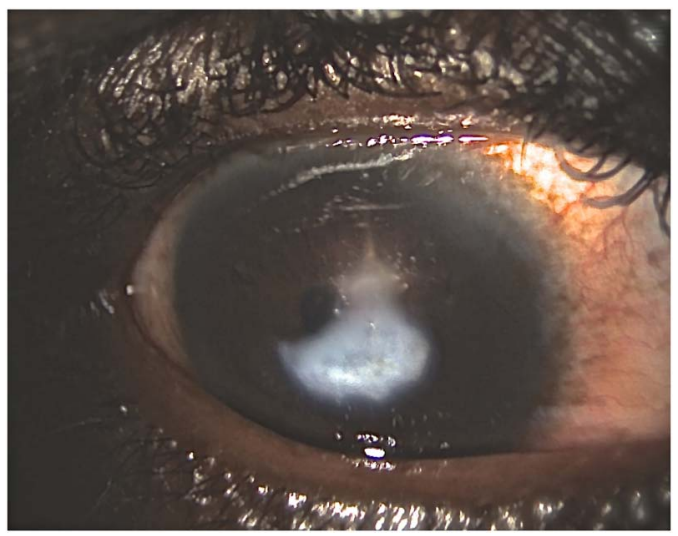

Figure 1 Anterior segment photograph of the right eye showing the adherent leucoma at the 6 o'clock position, secondary to measles infection.

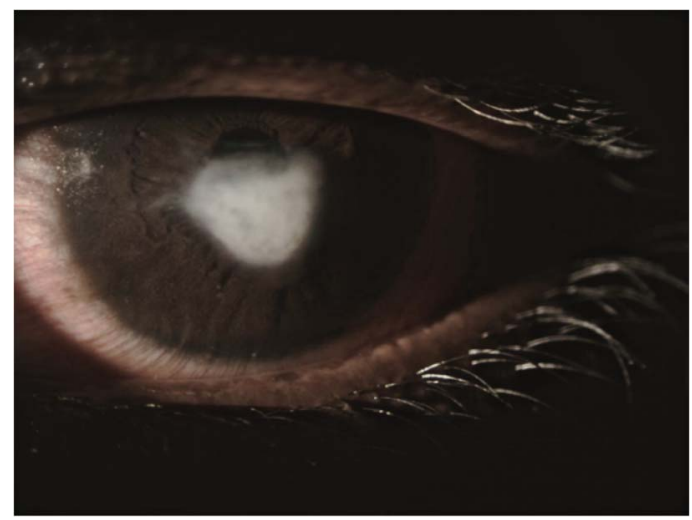

Figure 2 Anterior segment photograph of the left eye showing the adherent leucoma at the 6 o'clock position, secondary to measles infection.

\section{Learning points}

Alarming measles outbreaks have been recently reported in developed countries where vaccination is refused by many people due to popular and religious beliefs. ${ }^{1}$

- Although serious corneal complications are very rare in developed countries, the risk of importing measles from endemic countries persists and it must be kept in mind in the differential diagnosis of corneal leucoma, which encompasses a wide variety of infectious and inflammatory eye disorders. ${ }^{12}$

- An effective measles vaccination programme in developing countries can prevent postmeasles blindness. ${ }^{2}$

Contributors IL, DCS, FP and WR were the attending physicians. IL and DCS wrote the manuscript. FP and WR reviewed and approved the final manuscript.

Competing interests None declared.

Patient consent Obtained.

Provenance and peer review Not commissioned; externally peer reviewed.

\section{REFERENCES}

1 Foster A, Sommer A. Corneal ulceration, measles, and childhood blindness in Tanzania. Br J Ophthalmol 1987;71:331-43.

2 Sugerman DE, Barskey AE, Delea MG, et al. Measles outbreak in a highly vaccinated population San Diego, 2009: role of the intentionally undervaccinated. Pediatrics 2010;125:747. 
Copyright 2015 BMJ Publishing Group. All rights reserved. For permission to reuse any of this content visit http://group.bmj.com/group/rights-licensing/permissions.

BMJ Case Report Fellows may re-use this article for personal use and teaching without any further permission.

Become a Fellow of BMJ Case Reports today and you can:

- Submit as many cases as you like

- Enjoy fast sympathetic peer review and rapid publication of accepted articles

- Access all the published articles

- Re-use any of the published material for personal use and teaching without further permission

For information on Institutional Fellowships contact consortiasales@bmjgroup.com

Visit casereports.bmj.com for more articles like this and to become a Fellow 